\title{
Understanding the transgenerational orientation of family businesses: the role of family governance and business family identity
}

\author{
Julia Suess-Reyes ${ }^{1}$
}

Published online: 13 September 2016

(C) The Author(s) 2016. This article is published with open access at Springerlink.com

\begin{abstract}
The development of a transgenerational orientation is one of the most significant challenges that family businesses face and only a small number actually survive across generations. While prior research has focused on the business unit to provide us with a solid understanding of how corporate governance affects business performance and continuity, the role of the business family in the development of a transgenerational orientation has received less attention. To address this gap, this article applies a new systems and social identity theory framework to examine how family governance and business family identity can contribute to strengthening the transgenerational orientation of the business. A transgenerational orientation is defined as a decision premise to maintain the family's control over the business across generations. Using a large data set, findings show that the presence of family governance measures and the business family's identity are positively related to a transgenerational orientation of the business, with business family identity acting as a mediator. Thus, the development of family governance measures can foster communication within the business family and enhance the family members' emotional investment in the business which strengthens the transgenerational orientation in the business.
\end{abstract}

Keywords Family business · Business family · Family governance · Transgenerational orientation · Business family identity · New systems theory

JEL Classifications L2 · L21 · L29 · M14

Julia Suess-Reyes

julia.suess@wu.ac.at

1 Research Institute for Family Business, WU Vienna University of Economics and Business, Welthandelsplatz 1, 1020 Vienna, Austria 


\section{Introduction}

\section{The rise and fall of the Gucci Empire}

The story of Gucci commenced in 1906 when Guccio Gucci founded the famous brand in a Florentine saddlery. 47 years later Guccio died a millionaire passing his empire on to his sons Aldo and Rodolfo, little suspecting the severe family feuds that would follow. Aldo and Rodolfo expanded the business exponentially, but family quarrels and financial scandals led to significant adverse publicity. Family disputes also included legal proceedings in which Paolo Gucci, Aldo's son, sued his father and other family members involved in the business. They in turn filed countersuits to prevent Paolo from launching competitive leather products bearing the name 'Paolo Gucci Collection'. After 18 law suits, the Gucci family sold almost 50 percent of their shares to a Middle Eastern investment bank. Today, the Gucci group is owned by Kering, a French multinational business (CNBC 2016; Gordon and Nicholson 2008).

The story of the Gucci family is representative of the numerous other business families who suffer severe family problems. It emphasizes that, where there is a lack of governance within the family and the absence of a joint business family identity, the family can become a heavy burden on the business and in extreme cases can run the risk of causing the demise of businesses (Baus 2013). However, in contrast to this scenario, there are also many business families who serve as a great source of strength for the business and who work hard to uphold the family legacy. This willingness to safeguard the survival of the business across generations, known as the transgenerational orientation of family businesses (TGO), is one of the central topics in family business research (Chua et al. 1999; Habbershon et al. 2003; Lumpkin and Brigham 2011). As such, it constitutes the main distinguishing feature between family businesses and their counterparts (Chua et al. 1999; Lumpkin and Dess 2013; Zellweger et al. 2010). It plays a pivotal role in the development of theory concerning family businesses (Chrisman et al. 2005; Chua et al. 1999; Zellweger et al. 2012b) and attracts the continuous interest of family business researchers (cf. Brigham et al. 2014 or Lumpkin and Brigham 2011 for recent contributions).

From a practical point of view, the development of a TGO for the business constitutes one of the most substantial challenges that family businesses face. As the family tree grows, family ties tend to loosen, family members are more inclined to pursue diverging interests, their goals and involvement in the business may vary and their identification with the business often weakens (Zellweger and Kammerlander 2015). This paves the way for family conflicts regarding the strategic paths the business should pursue and may lead to opportunistic behavior among family members, which may affect the long-term success and sustainability of the business (Kidwell et al. 2012). Professional family business governance often serves as a response to these issues (Siebels and Knyphausen-Aufseß 2012). In particular, the role of the board of directors (Bammens et al. 2008; van den Heuvel et al. 2006) and 
its contribution to assuring the best possible performance of the family business take a predominant role in the literature (Anderson and Reeb 2004; Corbetta and Salvato 2004; Klein et al. 2005). However, only a comparatively small amount of studies have been conducted from the family-level perspective (Gersick and Feliu 2014; Suess 2014). This seems striking when we consider that the drivers of TGO such as family commitment to the business mission, the provision of patient capital, family stewardship (Le Breton-Miller and Miller 2006) and family entrepreneurial orientation (Zellweger et al. 2012b) are rooted largely within the family system. Hence, the family constitutes the decisive point of reference when it comes to safeguarding the survival of the business across generations and sound family business governance also requires governance measures within the family system to avoid a loss of family commitment and business continuity (Gersick and Feliu 2014). Understanding the longevity and the TGO of the family business therefore demands analysis conducted at a family rather than at the business level (Habbershon and Pistrui 2002; Uhlaner et al. 2012; Zellweger et al. 2012b).

To approach this interesting and relevant research gap, this article applies a new systems theory (Luhmann 1995; von Schlippe and Frank 2013) and social identity theory approach (Tajfel and Turner 1979; Turner 1984; Waldkirch 2015). Within this framework it is analyzed how family governance measures (short FGM) as a form of relational family business governance (Mustakallio et al. 2002) contribute to the creation of joint expectations that strengthen the business family's identity (BFI) as an expression of the family's identification with the business. In turn this may strengthen the TGO of the family business. The combination of new systems theory and social identity theory provides a fresh perspective on family business governance and the TGO of family businesses. It focuses on a social system perspective and explains how communication processes may create meaning and identification within this system and how this may lead to the development of a TGO. This approach provides an alternative to the dominant agency perspective on family business governance (Siebels and Knyphausen-Aufseß 2012) and reduces complexity levels, because it is easier to understand the rules and social processes within a group rather than the intentions and actions of single actors (Von Schlippe and Frank 2013). Family governance fosters communication within the business family (Brenes et al. 2011; Gilding 2000; Martin 2001; Mustakallio et al. 2002) and helps to maintain the cohesiveness of the business family as an entity that describes itself as an integral part of the business (Baus 2013). Defining the family as a part of the business can create meaning for the associated family. It is this meaning that strengthens and preserves the family's identity as a business family and enables it to develop joint expectations and plans towards cooperative value creation in the business and the safeguarding of the long-term survival of the business (Gilding 2000; Habbershon and Astrachan 1997; Jaffe and Lane 2004; Lansberg 1999; Mustakallio et al. 2002; Sundaramurthy 2008; Wimmer and Gebauer 2004). Hypotheses regarding the influence of family governance on business family identity and the TGO of the business are tested on a sample of 510 Austrian family businesses with dominant family ownership (i.e. more than $50 \%$ ). The findings indicate that family governance measures are positively related to the transgenerational orientation of the business with business family identity acting as a mediator. 
This article contributes to the debate on the transgenerational orientation of family businesses and family business governance in several ways: First, since the emergence of family business as a distinct field of research, TGO has been discussed as a constitutive characteristic of family businesses (Hall 1988; Handler 1994). Although the field has progressed enormously over recent decades and TGO still continues to be a central point of reference (Berrone et al. 2012; Zellweger et al. 2012a), our knowledge is still rather limited about the role of the family in fostering or impeding the TGO of the business. By introducing family governance and business family identity as drivers for TGO, this study contributes to the further understanding of this central concept in family business research. Second, this paper also contributes to family business governance research by empirically exploring the effects of family governance as a form of relational governance. Current literature emphasizes the value of family governance (Gersick and Feliu 2014; Suess 2014), yet is of a primarily narrative and case-based nature (Gersick et al. 1997; Lueger and Frank 2015; Neubauer and Lank 1998). Only recently researchers have started to study the relation between family governance and financial performance (Berent-Braun and Uhlaner 2012) as well as the relation to dividend policy and intra-family conflicts in family businesses (Michiels et al. 2015). However, our knowledge about how family governance is related to non-financial business and family goals is quite limited and constitutes an obvious gap in the literature (Gersick and Feliu 2014; Siebels and Knyphausen-Aufseß 2012). Therefore, this article provides initial evidence on how family governance is linked to business family identity and how this may influence one of the most central goals in family businesses - ensuring the continuity of the business and the safeguarding of the family legacy. Third, this article responds to recent calls for a more active integration of the family in family business research (Astrachan 2010; Dyer 2003; Uhlaner et al. 2012; Zachary 2011; Zahra and Sharma 2004) and thus counteracts the predominant focus on the business perspective which bears the risk of fragmented, incomplete conclusions (Dyer 2003).

\section{Theoretical framework}

\subsection{Transgenerational orientation of family businesses}

Transgenerational orientation and the longevity of family businesses are discussed in different streams of literature: (a) from the perspective of the transgenerational entrepreneurship paradigm (Habbershon and Pistrui 2002; Nordqvist and Zellweger 2010; Zellweger et al. 2012b) and (b) as a constitutive part of the "familiness" of family businesses (Frank et al. 2016). The former stream of literature differentiates between the entrepreneurial orientation of the business (Sieger and Zellweger 2013; Zellweger and Sieger 2012) and the entrepreneurial orientation of the family (Sieger and Zellweger 2013; Zellweger et al. 2012b; Zellweger and Kammerlander 2014) with both orientations acting as key drivers for transgenerational entrepreneurship in family businesses. 
In contrast to the transgenerational entrepreneurship paradigm, transgenerational orientation (TGO) does not emphasize the development of entrepreneurial mindsets within the family (Habbershon et al. 2010), but rather "represents a decision premise that frames decisions regarding the long-term survival and success of the business and intrafamily succession" (Frank et al. 2016, p. 22). Whilst not all family businesses can be said to be entrepreneurial, intra-family succession is frequently seen as crucial to preserving the family business status across generations (Frank et al. 2016). As such, TGO does not primarily emphasize the entrepreneurial spirit of business families, but constitutes an integral part of the "familiness" concept (Chrisman et al. 2005; Frank et al. 2016) which holds great potential to explain large parts of the distinctiveness and uniqueness of family businesses (Zellweger et al. 2010).

Furthermore, the transgenerational entrepreneurship paradigm is rooted in the resource-based view and focuses on "processes through which a family uses and develops entrepreneurial mindsets and family influenced capabilities to create new streams of entrepreneurial, financial and social value across generations" (Habbershon et al. 2010, p. 1). TGO, however, is anchored in new systems theory (Luhmann 1995). As a decision premise, TGO expresses the family's expectations towards the business and manifests itself in decision-making processes within the family business (Weismeier-Sammer et al. 2013). Hence, decision premises are neutral by definition and may not necessarily constitute a resource. However, they can lead to a competitive advantage for the family business if they meet the VRIN criteria (Frank et al. 2016).

\subsection{New systems theory}

New systems theory (nST) does not focus on persons, but on communication as the constitutive element of a social system (Luhmann 1995). It looks at the processes by which elements of communication are connected to one another, the underlying expectations and the inherent structures which shape these patterns (von Schlippe and Frank 2013). This approach diminishes complexity levels, since it is easier to understand the rules of the game rather than individual players and their relationships within a social system (Simon 2012). New systems theory (Luhmann 1995; von Schlippe and Frank 2013) conceptualizes the family business as a social system consisting of at least two structurally coupled systems - the family and the business system. As a theory of great reach, it enables a comprehensive understanding of the particularities and complexities of family businesses, thus it helps to cope with the present fragmentation of the field (von Schlippe and Frank 2013). From an nST point of view, a family business is defined as "a communication system incorporating the decision premises shaped by a family" (Frank et al. 2016, p. 4). In a similar vein, a business family is defined as the communication system of a self-defined group of the family that is involved in business-related communication and capable of influencing the decision premises in the business. This business-related communication within the family system strongly shapes the family's self-perception of being (or not) being a business family. This self-perception is established in business-related communication within 
the family system. Family governance measures constitute communication forums for the family which serve the creation of self-descriptions as a business family and the establishment of decision premises regarding the family's relation to the business. Self-descriptions generally exceed self-observations and hence represent a specific accomplishment of the family as a social system (Frank et al. 2016; Seidl 2003).

According to Luhmann (1995), social systems such as family businesses are autopoietic, self-referential and operationally closed. This means that the system's environment cannot directly affect the system (Maul 1993). Any external impact is processed by system-inherent meaning structures that demarcate the system from its relevant environment (von Schlippe and Frank 2013). Meaning structures within a system evolve with communicated decisions which are based on former decisions, creating so called "decision premises" that provide a framework for numerous future decisions in an organization (Luhmann 2011; Seidl 2005). These decision premises are usually long-lasting. They provide stability to the system (Luhmann 2011) and reduce the complexity of decision-making (Luhmann 1995; Seidl 2005). A TGO often represents a central decision premise in a family business context (Frank et al. 2016) as well as a pre-condition for succession. However, family businesses do not necessarily need to have experience with succession to build a TGO. Rather a TGO focuses on the future and serves as a "higher-order heuristic that, in matters of intertemporal choice, provides a dominant logic for decisions and actions" (Lumpkin and Brigham 2011, p. 1149). Therefore, a transgenerational orientation has emerged as a dominant distinctive feature of family businesses (Chua et al. 1999; Habbershon et al. 2003; James 1999; Lansberg 1999; Lumpkin et al. 2010; Lumpkin and Brigham 2011; Ward 1997; Zellweger et al. 2010) and understanding how a TGO develops is of central relevance to family business research.

Family influenced decision premises such as a TGO can manifest themselves in documents such as family constitutions. This is illustrated in the following example, taken from a family constitution: "The extended family is seen as the root of the business. For the founder, but also for his sons, it is of great importance that the lifework persists and that the entrepreneurial spirit also continues and grows in the subsequent generations. The involvement of qualified and willing persons from the extended family in the business, therefore, needs to be actively promoted". "The overarching decision premise in this example is to preserve the family's influence in the long run (thus to maintain a TGO) and to pursue the founder's entrepreneurial spirit.

\subsection{Social identity theory}

Social identity theory has its origins in the actor-centered theories of sociology and psychology and has been elaborated and extended to groups, social categories and organizations (Whetten et al. 2014). According to social identity theory, identity can be seen as an individual, relational or collective construct (Waldkirch 2015). In

\footnotetext{
1 Taken from a family constitution recently used for the preparation of a case study by the author
} 
general, it refers to how persons, social groups or organizations define "who" they are (Albert and Whetten 1985). Social identity theory is based on the assumption that persons identify with the social groups they belong to and act in favor of their "in-groups" (Tajfel et al. 1971; Turner et al. 1979). The degree of "belongingness" to or "oneness" with groups such as organizations, religious institutions or football clubs is expressed through the concept of social identification (Ashforth and Mael 1989). Identification with a group requires three components: (a) a cognitive component, i.e. being aware of group membership, (b) an evaluative component, i.e. attaching value to group membership and (c) an emotional investment component with regards to awareness and evaluations e.g. experiencing the group's success or failure as a personal one (Tajfel 1982). The higher the degree of an actor's identification with a social group or organization, the stronger the bonds of attachment and commitment to that group tend to be (Whetten et al. 2014).

Social identity theory represents a "refreshing alternative to established theorizing" (Reicher et al. 2010, p. 61) and emerges as a useful theory for the explanation and prediction of group behavior (Waldkirch 2015). With regards to family businesses, social identity theory provides a way of capturing and explaining "the meaning structures of the family and business component of a "family business" (Whetten et al. 2014, p. 480). Current research emphasizes that family businesses are hybrid identity organizations (Whetten et al. 2014) which indicates a need to differentiate between a business family identity and a family business identity (Frank et al. 2016). This article focuses on the business family's identity which is associated with a decision-making premise that aims to safeguard the family's identification with the business. This business family identity is a form of sense-making for the family, "a more or less shared conception of "who we are", (Whetten et al. 2014, p. 483), which is nurtured by the business as a source of sensemaking. The beliefs and values within the business family are continuously expressed in the course of communication and communication in turn provides an interpretive belief system to the business family and its members (Gioia 1998; Zellweger et al. 2010). Family governance measures constitute forums for enhancing communication within the business family (Brenes et al. 2011; Gilding 2000; Martin 2001; Mustakallio et al. 2002), for enabling family participation in the business and for aligning family beliefs and values with regards to business continuity. As such they foster the family's identification with the business and contribute to maintaining the business family as a cohesive entity that describes itself as an integral part of the business (Baus 2013).

\section{Rationale and hypotheses development}

In this section, the author develops a rationale about the hypothesized relations between family governance measures (FGM), business family identity (BFI) and transgenerational orientation (TGO). The underlying model is outlined in Fig. 1. 


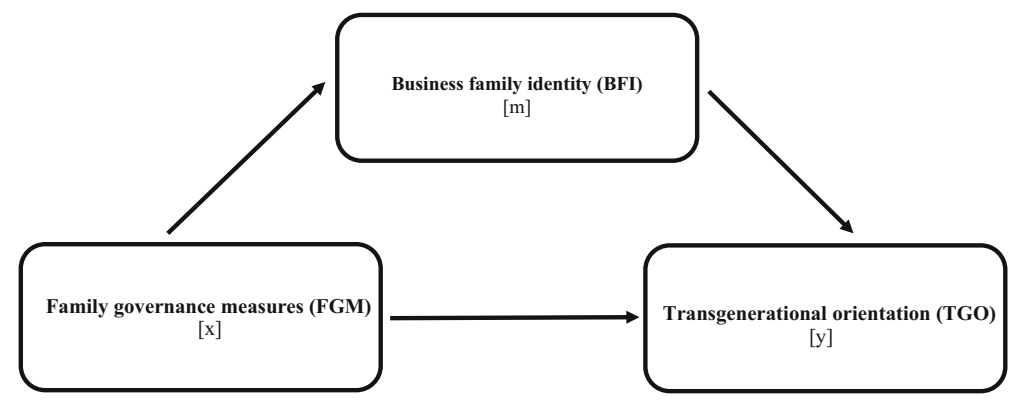

Fig. 1 Mediation model

\subsection{Family governance measures and transgenerational orientation}

"Governance structures are the engine of continuity for family companies" (Lansberg 1999, p. 282). Governance practices in family businesses differ from those employed in non-family businesses (Bammens et al. 2008; May 2012; Siebels and Knyphausen-Aufseß 2012). In family businesses, the success of the business depends to a large degree on the associated family (James 1999); the way the family organizes itself and its relation to the business (Olson et al. 2003). Therefore, successful family businesses often complement their business governance through the development of FGM (Koeberle-Schmid et al. 2012). While business governance (i.e. the top management team, the board of directors and the shareholder meeting) serves the operating firm through the organization of administration, the control of management and the provision of advice (Gallo and Kenyon-Rouvinez 2005), family governance serves a different function in family businesses (Gersick and Feliu 2014). Family governance aims to strengthen family cohesion, channel the family's influence on the business and develop joint expectations and plans for the future of the business (Mustakallio et al. 2002). Family governance can thus be seen as an integral part of the family business governance system in family businesses (Klein 2009; Siebels and KnyphausenAufseß 2012). As a kind of informal form of governance, it supplements and complements contractual family business governance mechanisms (Calabrò and Mussolino 2013; Poppo and Zenger 2002). However, not all types of informal governance mechanisms may purposefully be considered as family governance. Trust or relational norms, for instance, play an important role in almost any transaction and in the governance of any organization. As such, they may also be important antecedents for the development of FGM (Martin 2001), however they are not primarily designed to fulfill the classical functions of family governance, i.e. fostering cohesion, coordinating the family's influence on the business and planning the future of the business.

Business families often make use of their own, unique set of FGM attuned to family values, the stage of business development and degree of family complexity (Jaffe and Lane 2004). One of the most widely spread forms of FGM are informal and formal family meetings (Neubauer and Lank 1998; Martin 2001) which are 
essentially recurring assemblies in which the business family meets to discuss business issues (Habbershon and Astrachan 1997; Neubauer and Lank 1998) and to plan for the future of the business. The family council as a select group of the business family (Berent-Braun and Uhlaner 2012) provides a structured forum that enables the family to express its values and expectations for the business in order to develop strategies that protect the family's long-term interests in the business (Gersick et al. 1997). The family constitution can be described as a normative agreement of fundamental guidelines and principles (i.e. decision premises) according to which the business family organizes its relation to the business (Berent-Braun and Uhlaner 2012, Neubauer and Lank 1998). In this regard family constitutions assist the business family in formalizing its expectations regarding responsibilities and rewards related to business membership (Botero et al. 2015; Fuetsch and Frank 2015).

From a theoretical perspective, FGM serve as communication forums to manage the family's influence over the business. Within these forums, the business family develops rules for the family's involvement in the business. When approaching the succession phase, families increasingly turn to FGM to determine their current position, to formally structure areas of family influence and to assign basic rules for task fulfillment (Froschauer and Lueger 2015). The need for family governance is increasingly common in mature family businesses as the number of active and passive owners tends to increase with every succession (Hack 2009; Lansberg 1999). The larger the number of family members and family generations (Brenes et al. 2011) the more complex communication and decision-making processes become (Hack 2009). Non-active family members frequently feel estranged from the business due to a lack of communication (Mustakallio et al. 2002). Therefore, more complex business families tend to have a greater need for information, coordination and establishing joint expectations about central business goals (Fahed-Sreih and Djoundourian 2006; Habbershon and Astrachan 1997; Suáre and Santana-Martín 2004). In this respect, FGM can provide helpful structures to enhance communication within the business family (Brenes et al. 2011; Gilding 2000; Martin 2001; Mustakallio et al. 2002). Open communication within the business family is essential to facilitate the development of joint expectations about the future of the business (Gilding 2000; Habbershon and Astrachan 1997; Jaffe and Lane 2004; Mustakallio et al. 2002). Regular communication through FGM makes the business family more likely to develop a sense of commitment and responsibility for the continuity of the business (Blumentritt et al. 2007).

Initial empirical evidence with regards to family councils indicates that their use is positively associated with succession planning (Blumentritt 2006) and that family businesses which use family councils tend to enjoy improved succession performance (Chittoor and Das 2007; Craig and Moores 2002). In a similar vein, less formal FGM such as family meetings can play a pivotal role when it comes to conveying a feeling of responsibility for the business family (Aronoff and Ward 2011). Furthermore, family meetings tend to be positively associated with the longevity of the business (Astrachan and Kolenko 1994). This is in line with studies which conclude that business families which use family governance tend to see improved prospects for the survival of their business (Fahed-Sreih 2009). Business 
families that make use of different forms of FGM might therefore be more likely to develop a TGO for the business which is summarized in the following hypothesis:

Hypothesis 1: A stronger presence of family governance measures positively affects the transgenerational orientation of the family business.

\subsection{Family governance measures and business family identity}

The development of a TGO depends largely on the business family which is the decisive point of reference for family business continuity. While some business families can be a source of great strength for the business, others can be a potential weakness (Baus 2013). Therefore, understanding how a TGO develops requires examining the family's identification with the business and how FGM can contribute to strengthening this identification.

Generally, the identity of a social system is based on self-descriptions and captures the collective self-conception of a system (Seidl 2003). In a family business context, business family identity is achieved if family members develop an emotionally-tied self-concept of being part of a business family (von Schlippe et al. 2009) that identifies itself with the business. Such self-descriptions emerge from communication processes (Luhmann 1984, 1995). They go beyond self-observations (Luhmann 1984; Seidl 2003) and entail expectations (Luhmann 1995). Communicated expectations related to membership in a social system increase the understanding of values and norms (Smidts et al. 2001) which may in turn strengthen the group members' involvement and sense of belonging to the group (Lawler 1989).

FGM can be understood as communication forums that support the family in generating and aligning expectations and formulating decision premises with regard to the business system (Mustakallio et al. 2002). Therefore, business families which communicate and exchange information on a regular basis are more likely to develop a common point of view regarding the business (Sorenson et al. 2009). Indeed, open communication about business issues, participation in decisionmaking and reflections on the joint history can foster the family's commitment to and identification with the business (Smidts et al. 2001; von Schlippe et al. 2009). Furthermore, shared narratives can contribute to imprinting the family's entrepreneurial legacy on to the next generation and to make it survive far beyond the founder generation (Jaskiewicz et al. 2015). Family meetings are a way of expressing shared beliefs in the family (Habbershon and Astrachan 1997; Mussolino and Calabrò 2014). Especially next generation family members will develop a better understanding of business activities and give meaning to the continuity of the business (Jaskiewicz et al. 2015). In a similar way to other FGM, family meetings enable the participation of a wider group of family members in business matters and align family beliefs and values with regards to business continuity. Being part of a business family can be a source of sense-making (Whetten et al. 2014) that is frequently related to the family members' self-esteem (Dyer and Whetten 2006). By creating joint stable reference points for the family, FGM might therefore strengthen the family's commitment to and identification with the business. As such FGM can 
contribute to establishing and strengthening a self-concept as a business family that defines itself as an integral part of the business (Labaki 2011; Pieper and Astrachan 2008; Süss-Reyes 2015). It stands to reason that business families that use different forms of FGM are more likely to possess a stronger business family identity (von Schlippe et al. 2009) and attach a higher importance to maintaining the family as an integral part of the business which is summarized in the following hypothesis:

Hypothesis 2: A stronger presence of family governance measures positively affects the business family's identity.

\subsection{The mediating role of business family identity in the relation between family governance and transgenerational orientation}

"When a family makes the business its central priority, its identity as a family becomes enmeshed with that of the business. The notion that the business is more important than anything else gets carried into the future." (Ward 2004, p. 57).

Family governance measures create structures within the business family that strengthen the family's identification with the business (Baus 2013). When family members draw affective significance and value from membership in the business family, they may go great lengths to retain the business in family hands. They feel that they share a joint responsibility for the continuity of the business and this may enhance their motivation to contribute to the business (Zellweger et al. 2010). A strong BFI is one of the utmost competitive assets of well-functioning family businesses. Consequently, successful family businesses are aware that it is crucial to invest efforts to ensure the business family's continued commitment to and identification with the business in order to develop and sustain a family legacy (Lansberg 1999). Family members only identify with the business if it creates meaning for them and when they perceive a feeling of belonging. The family members' sense of belonging to the business usually reaches beyond formal business-related duties (Thoits and Virshup 1997) and often extends beyond purely financial benefits (Wimmer et al. 2005) towards creating a sense of shared destiny. This sense of belonging and shared destiny builds a mutual basis that leads family members to perceive the fulfillment of business obligations as a source of pride (Sundaramurthy and Kreiner 2008).

Generally, social identification favors actions that are in line with identity and encourages support for groups sharing this identity (Ashforth and Mael 1989). In this way, identity provides a shared understanding for behavioral norms concerning group behavior and makes group behavior predictable (Ravasi and Schultz 2006). In the case of business families, a TGO is a way for the family "to maintain a stable self-concept of the family over time" (Zellweger et al. 2011, p. 8). Thus, keeping the business in family hands constitutes an expression of making the family an enduring component of the business and reflects a coherent past, present and future appearance as a business family (Zellweger et al. 2011). If family governance is functional, it strengthens the family members' emotional investment in the 
business. This way, family members see the business as an extension of themselves and perceive its successes as personal success whilst also suffering from business defeats (Deephouse and Jaskiewicz 2013). A strong BFI contributes to imprinting the family legacy on to the next generation of family members and to fostering family loyalty towards the business. Family governance is a valuable means of strengthening the BFI. However, if FGM fail to fulfill this function, they remain "empty" structures or purely formal acts that do not contribute to the family members' emotional investment in the business. Thus, if the family does not achieve the development of a joint identity as a business family that feels loyal to the business and works together to realize common goals, FGM remain ineffective (or even dysfunctional) and it is unlikely that a TGO will develop. This absence of a joint business family identity can encourage feelings of estrangement, disengagement, opportunistic behaviors and family conflicts which affect the long-term success and sustainability of the business (Kidwell et al. 2012). The case of the Gucci family, mentioned at the beginning of this article, provides an illustrative example of how such behaviors not only harm family cohesion, but can also put business continuity at risk. In contrast, if FGM are effective and contribute to the family members' identification with the business, the family shares a sense of responsibility for the future development of the business and questioning the TGO might seem inappropriate or even heretical (Lansberg 1999). Hence the presence of a BFI is likely to transfer into a common understanding with regards to business continuity resulting in a TGO for the business. Consequently, this means that FGM can only foster the TGO for the business if they are supported by the business family and help to strengthen the family's identity as a business family. In other words, FGM only nurture a TGO if they help to enhance the BFI. BFI is therefore assumed to mediate the relation between FGM and TGO which is summarized in the following hypothesis:

Hypothesis 3: The relation between family governance measures and the transgenerational orientation of the family business is mediated by the business family's identity.

\section{Methods}

\subsection{Data collection and sample description}

The survey was conducted on a random sample of family businesses. This sample was extracted from an Austrian online database and consists of businesses that employed five or more persons in 2012 and were founded prior to 2008 (in order to exclude family businesses that are still confronted with start-up challenges). Out of these 51,129 businesses, a random sample of 5500 firms was taken. As databases listing family businesses were not available, data collection was arranged in two steps to ensure an acceptable response rate: (1) Telephone interviews were conducted with the 5500 businesses in early summer 2013. In total 4153 businesses were reached over a period of five weeks. Out of these 1674 businesses (40\%) were 
family businesses (according to a self-assessment of the telephone partner) and accepted the request to participate in the online survey. (2) The online tool LIMESURVEY was used to distribute the survey. Following the initial telephone interview, each business received a link to the online questionnaire. Reminders were sent after one week (1333) and after two weeks (887). In total, 612 questionnaires were returned, corresponding to a response rate of $34 \%$ (Frank et al. 2016). The questionnaire was only completed by family members, in most cases the owners (79 \% of the final sample; multiple answers were possible) and/or the managers of the family business (48\% of the final sample).

In order to specify the sample of analysis, a family business was defined as a business of which the family holds more than $50 \%$ of the ownership. This ensures sufficient voting rights and the potential to shape the transgenerational orientation of the business (Chua et al. 1999). After filtering out businesses with less than $50 \%$ family ownership and cases with missing data on the variables of interest, a sample of 510 family businesses was available for further analysis. In this sample, $84 \%$ were small, $8 \%$ medium-sized and another $8 \%$ were large businesses (according to the categorization of the European Commission 2003). The average business age was 50 years (median: 42). Accordingly, $34 \%$ of the businesses were in the first, $32 \%$ in the second, $24 \%$ in the third and $6 \%$ in the fourth generation of the family. Another $4 \%$ stated that they were in their fifth generation or beyond. In terms of the ownership distribution in the sample, a mean of $99 \%$ of the shares (median: $100 \%$ ) are family-owned. In $67 \%$ of the businesses, only one generation holds ownership. In $31 \%$ of the businesses, two generations, and in $2 \%$ even three generations are owners of the business. In $63 \%$, only one generation is active in the management of the family business, whereas in $35 \%$ and $2 \%$ of the businesses, two and three generations, respectively, manage the business together. With regards to the main industries represented in the sample, the businesses specified that $33 \%$ are predominantly active in the manufacturing industry, $64 \%$ in services and $41 \%$ in trade (multiple answers were possible).

\subsection{Measures}

Dependent variable: Transgenerational orientation (TGO) was measured by the subscale "transgenerational orientation" taken from the "Family Influence Familiness Scale (FIFS)" (Frank et al. 2016). While Berrone et al. (2012) also provide a measure for the "renewal of family bonds through dynastic succession" (p. 267) that is similar to TGO, the scale provided by Frank et al. (2016) is more concise. Furthermore, Berrone et al. (2012) root their scale in a "socioemotional wealth" framework which constitutes an extension of the behavioral agency theory, whereas the scale by Frank et al. (2016) is consistent with the theoretical framework of new systems theory used in this article. Therefore, the scale developed by Frank et al. (2016) was chosen to measure TGO. This scale comprises three items that were introduced by the question "How do the following statements apply to your family business?" and followed by the introductory statement "In our family business we take great care...". This wording was designed to address the conditions that frame decisions, i.e. decision premises. The item set included “...to think in generations”, 
"...to avoid selling the company to non-family members", and "...that the company can be passed on to the next generation". Respondents had to rate the items on a 6-point Likert scale ranging from (1) "does not apply at all" to (6) "completely applies". The aggregated result of all items representing TGO in the form of the calculated mean was used for analyses. Reliability analysis indicates a good internal consistency of the scale, with a Cronbach's alpha of 0.85 .

Mediator variable: Similar to TGO, business family identity (BFI) was developed in the context of the "Family Influence Familiness Scale (FIFS)" (Frank et al. 2016). This scale comprises five items that were introduced by the question "How do the following statements apply to your family business?" and followed by the introductory statement "In our family business we take great care". The item set included "...that the family is emotionally tied to the company", "...that family members stick together", "...to spend enough time as a family also outside the company", "...to act as one family in public", "...that all family members working in the company give their best". Respondents had to rate the items on a 6-point Likert scale ranging from (1) "does not apply at all" to (6) "completely applies". The aggregated result of all items representing BFI in the form of the calculated mean was used for analyses. Reliability analysis indicates a good internal consistency of the scale, with a Cronbach's alpha of 0.81 .

Independent variable: Family governance was measured by a slightly adapted version of the scale developed by Mustakallio et al. (2002) which comprises four variables: informal family meetings, formal family meetings, family council and family constitution. For each of these aspects, respondents were asked to indicate whether they use this measure or not $(0=$ no, $1=$ yes $)$. In a similar way to the study conducted by Mustakallio et al. (2002), all four family governance measures (FGM) were combined by building a sum score. This approach was chosen, because the total number of different FGM is an indicator for the degree of institutionalization of family governance. An institutionalized family governance consisting of various measures is likely to have a greater effect on the family and the business than single random measures alone.

Control variables: Multiple control variables were used to ensure a correct model specification. First, business size and business age were controlled for, as recent evidence (Brigham et al. 2014) indicates that both variables positively correlate with the existence of a TGO of the business. Business size might be an especially relevant factor for predicting TGO due to the fact that larger family businesses tend to possess more employment facilities for the next generation of family members (Zellweger et al. 2011). To measure business size, the natural logarithm of the number of employees working for the business in 2012 (the year prior to the survey) was used in order to provide a more linear sample distribution. In a similar vein, for business age, the natural logarithm of the number of years since the business was founded for the first time (to avoid confusion in case of business reorganizations) was calculated.

Second, family businesses that employ a larger number of family members may exhibit higher levels of TGO, e.g. due to altruism in the business family whose 
members want to safeguard jobs and income deriving from ownership shares in the long run (Schulze et al. 2001). Therefore, the naturally logarithmized number of family members working in the business (in order to provide a more linear sample distribution) was also taken into account for regression analyses. Third, the presence of multiple generations of family members in the business typically reflects the business family's inclination to think long term (Brigham et al. 2014) and thus might be positively related to the TGO of the business. This assumption was controlled for by the number of family generations involved in business management and the number of generations holding business ownership. Both controls were operationalized through a categorical variable (ranging from one to three generations) which was transformed into a dummy variable for regression analysis. These transformed variables indicate whether only one generation (coded 0 ) or more than one generation (coded 1) was involved in business management or ownership respectively.

The detailed operationalization of all variables can be found in "Appendix".

\section{Findings}

\subsection{Descriptive statistics and correlations}

Table 1 displays the means, standard deviations and the bivariate correlation coefficients between all variables included in the analysis.

The majority of businesses implemented at least one family governance measure (FGM). Informal family meetings were the most common measure. These were in use in $98 \%$ of the family businesses, whereas only $45 \%$ of the businesses hold formal family meetings. Family councils and constitutions were less common with $10 \%$ and $9 \%$ of the businesses respectively having them. Taking all FGM under research together, they can be seen to positively correlate with transgenerational orientation (TGO; $\mathrm{r}=0.16, p<0.01$ ) and with business family identity (BFI; $\mathrm{r}=0.15, p<0.01$ ). Considering that FGM are used for multiple purposes (e.g. for managing family conflicts, channeling the family's influence on the business, strategic planning) and that the respondents were not asked for the specific purpose of their FGM, the moderate level of the correlations seems to be plausible. In other words, although the specific function of the FGM is unknown, they significantly correlate with BFI and TGO. Furthermore, the results indicate that business families with a strong BFI exhibit a higher level of TGO $(r=0.35, p<0.01)$.

Since all data was gathered within the same questionnaire, the possibility of common method bias was tested using Harman's one-factor test (Podsakoff and Organ 1986). For this purpose, all variables under research were entered into an unrotated factor analysis to evaluate the number of factors emerging from the data. Four factors with eigenvalues greater than 1.0 were extracted. Altogether, they account for $66 \%$ of the variance, with the first factor explaining $25 \%$ of the variance. Thus, the results provide support for the conclusion that the variables are separate factors. To detect potential multicollinearity problems, Variance Inflation Factor (VIF) scores were assessed for the main model (model 4; see Table 2). 


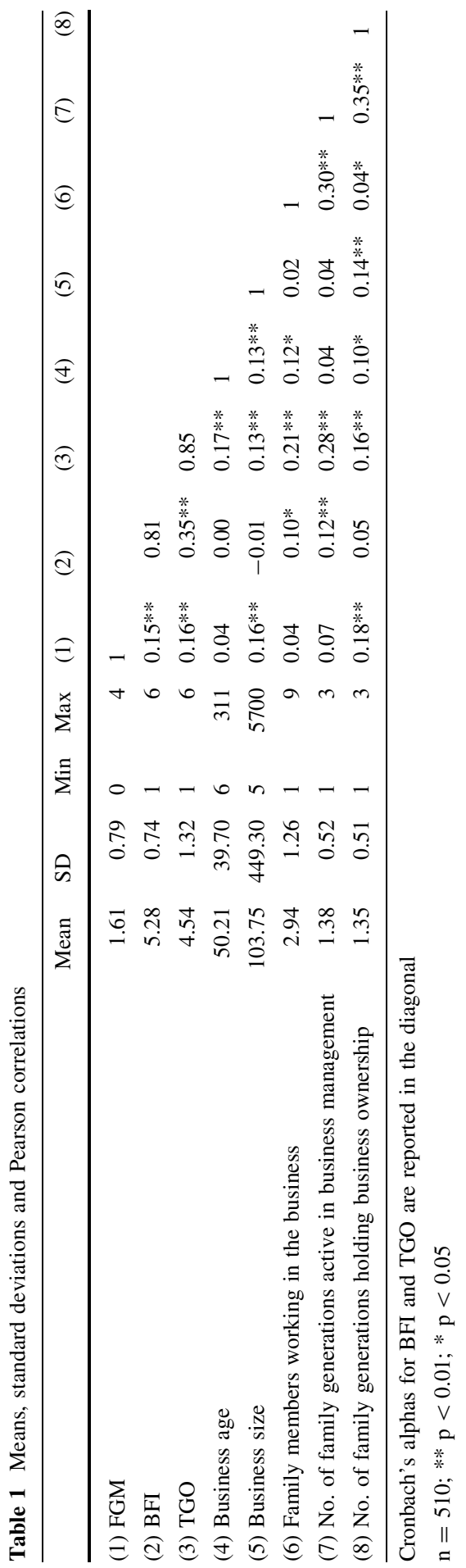


Table 2 Regression models

\begin{tabular}{|c|c|c|c|c|}
\hline & Model 1 & Model 2 & Model 3 & Model 4 \\
\hline \multirow[t]{2}{*}{ Independent variables } & Controls & Controls & Controls & Controls \\
\hline & & FGM & FGM & FGM \\
\hline Mediator variable & & & & BFI \\
\hline \multirow[t]{2}{*}{ Dependent variable } & TGO & TGO & BFI & TGO \\
\hline & Beta values & Beta values & Beta values & Beta values \\
\hline \multicolumn{5}{|l|}{ Controls } \\
\hline Business size $^{\mathrm{a}}$ & $0.152 * * *$ & $0.133 * *$ & -0.049 & $0.147 * * *$ \\
\hline Business age $^{a}$ & $0.120 * *$ & $0.122 * *$ & 0.033 & $0.112 * *$ \\
\hline $\begin{array}{l}\text { Family members working } \\
\text { in the business }\end{array}$ & $0.119 * *$ & $0.117 * *$ & 0.081 & $0.093 *$ \\
\hline $\begin{array}{l}\text { No. of family generations } \\
\text { active in business } \\
\text { management }^{\text {b }}\end{array}$ & $0.217 * * *$ & $0.215^{* * *}$ & 0.075 & $0.192 * * *$ \\
\hline $\begin{array}{l}\text { No. of family generations } \\
\text { holding business } \\
\text { ownership }^{\text {b }}\end{array}$ & 0.036 & 0.023 & 0.017 & 0.018 \\
\hline FGM & & $0.100 *$ & $0.144 * *$ & 0.057 \\
\hline BFI (mediator) & & & & $0.297 * * *$ \\
\hline$R^{2}$ & $0.150 * * *$ & $0.160 * * *$ & $0.041 * *$ & $0.244 * * *$ \\
\hline Adjusted $R^{2}$ & $0.142 * * *$ & $0.150 * * *$ & $0.030 * *$ & $0.233 * * *$ \\
\hline$F$ & $17.821 * * *$ & $15.916 * * *$ & $3.623 * *$ & $23.145^{* * *}$ \\
\hline
\end{tabular}

$\mathrm{n}=510, * * * p<0.001 ; * * p<0.01 ; * p<0.05$

a Converted to a natural logarithm (ln) of the original values

b Transformed into a dummy variable $(0=$ only one generation, $1=$ more than one generation $)$

Altogether, the highest VIF score was 1.3 meaning that the independent variables included in the analyses are robust against multicollinearity problems.

\subsection{Regression models}

According to the requirements for mediation outlined by Baron and Kenny (1986), four conditions need to be fulfilled for mediation: First, the predictor variable (FGM) must significantly predict the outcome variable (TGO) which was tested in model 2 (hypothesis 1). Second, the predictor variable (FGM) must significantly predict the mediator (BFI) which was tested in model 3 (hypothesis 2). Third, the mediator (BFI) must significantly predict the outcome variable (TGO) which was tested in model 4 (hypothesis 3). Fourth, the effect of the predictor variable (FGM) on the outcome variable (TGO) needs to decrease in significance and/or magnitude once BFI is taken into account. To test these assumptions, multiple regression analysis was performed for each model. The results are presented in Table 2.

In model 1, only the dependent variable (TGO) was regressed onto the control variables by considering standardized regression coefficients $(\beta)$ and the 
significance of these weights. Business size $(\beta=0.152, p<0.001)$, business age $(\beta=0.120, p<0.01)$, the number of family members working in the business $(\beta=0.119, p<0.01)$, and the number of family generations active in business management $(\beta=0.217, p<0.001)$ proved to be significant. In a next step, hypothesis 1 was tested in model 2. FGM are a positive predictor for TGO $(\beta=0.100, p<0.05)$. This model explains $15.0 \%(p<0.001)$ of the variance in TGO. In model 3, the effect of the predictor variable (FGM) on the mediator variable (BFI) was evaluated. In this case, none of the control variables were significant. FGM, however, are positively related to BFI $(\beta=0.144, p<0.01)$ which supports hypothesis 2 .

To assess whether BFI acts as a mediator between FGM and TGO, model 4 was tested. Full mediation is assumed when the effect of the predictor variable and the dependent variable decreases to a point where it is not significant anymore after the mediator variable has been entered into the analysis. If the effect decreases but remains significant after the inclusion of the mediator variable as an additional predictor, partial mediation occurs (Hair et al. 2010 referring to Cohen and Cohen 1983). As shown in model 4, the effect of FGM on TGO both decreases in magnitude and is ceases to be significant once BFI is entered as a mediator ( $\beta=0.057, \mathrm{p}>0.05)$. The effect of BFI on TGO, in contrast, seems to be strong and highly significant $(\beta=0.297, \mathrm{p}<0.001)$. Thus, according to the above definition, full mediation is supported by the regression analysis. To test for the significance of the mediating effect, a Sobel test (Sobel 1982), including control variables as covariates, was performed. The results confirm the significance of the indirect effect of FGM on TGO via BFI $(z=2.91, p<0.01)$. Hence, hypothesis 3 is supported. The final model including control variables, FGM and BFI explained $23.3 \%(p<0.001)$ of the variance in TGO.

\section{Discussion and conclusion}

\subsection{Contributions to theory}

This paper contributes to the field of family business research in at least three ways:

First, it adds to the discussion on family business governance, primarily in terms of showing the value of family governance measures for business continuity. To date, family business governance literature has been focused on the contractual governance sphere with an emphasis on board structure and the related impact on business performance. However, scholarly attention addressing the value of family governance remained comparatively scarce (Siebels and Knyphausen-Aufseß 2012). As a kind of informal, legally non-binding form of governance, family governance supplements and complements contractual family business governance mechanisms (Calabrò and Mussolino 2013). The findings of this study confirm the role of family governance measures (FGM) in strengthening the family's identification with the business and in fostering the transgenerational orientation of the business. Thus this study emphasizes that a sole focus on the proper organization of the businessrelated, contractual governance may not suffice to safeguard transgenerational 
business continuity. While business governance ensures performance and competitiveness, family governance serves to enhance the family's commitment to and identification with the business. Business families that focus solely on professional business governance with a disregard of family governance risk a loss of commitment and continuity in the long run (Gersick and Feliu 2014). Furthermore, the simultaneous fulfillment of family and business governance functions by contractual governance bodies (as for instance the board of directors) may have disruptive effects on the business, as family matters can be time-consuming, time which they may then lack for the fulfillment of other business governance functions including those of ensuring business performance and competitiveness (KoeberleSchmid et al. 2009).

Second, this study also offers an interesting point of intersection with the transgenerational entrepreneurship paradigm (Habbershon and Pistrui 2002; Habbershon et al. 2010; Nordqvist and Zellweger 2010; Zellweger et al. 2012b). Similar to the concept of transgenerational orientation, this paradigm takes a longitudinal perspective to explain how entrepreneurial, financial and social value is created not only for the current, but also for future generations (Zellweger et al. 2012b). A recent study by Jaskiewicz et al. (2015) on transgenerational entrepreneurship concludes that families who are entrepreneurial across generations keep the entrepreneurial legacy alive through narratives on the family's achievements in the past. They succeed in imprinting their entrepreneurial spirit to next generation family members and motivating them to continue the history. Furthermore, transgenerational entrepreneurship is nurtured through "strategic education" (training the next generation towards entrepreneurial opportunity recognition), "entrepreneurial bridging" (temporary cooperation of at least two generations to encourage entrepreneurship) and "strategic succession" (arranging succession in a way that resources required for entrepreneurship are protected). In a comparable way to an entrepreneurial legacy, a strong business family identity can be conducive to the transgenerational continuity of the business. Family governance measures provide a framework to foster this identity and to encourage the next generation's entrepreneurial spirit. Similar to Jaskiewicz et al. (2015), this article emphasizes that business continuity does not happen accidentally, but needs clear and timely governance decisions. Long-lived family businesses tend to integrate children in business matters from early on. They imprint their entrepreneurial spirit, plan the offspring's education and career strategically and give them enough time to learn on the job before they hand the business over. In this regard, a key function of FGM is to foster the business family's collective goal orientation, particularly with regards to the entrepreneurial goal of creating value together as a family in the business across generations. As such, FGM increase the effectiveness of the business family and strengthens its transgenerational entrepreneurial effort for the business (BerentBraun and Uhlaner 2012).

Third, this article also adds to the discussion on "familiness" in family businesses (Frank et al. 2016; Zellweger et al. 2010). The notion of familiness is frequently structured as a three-dimensional concept comprising of a componentsof-involvement, essence and organizational identity sphere (Zellweger et al. 2010). In a recent contribution, the familiness construct has also been measured in terms of 
a multidimensional theory-based scale called the "Family Influence Familiness Scale" (FIFS) (Frank et al. 2016). Explaining how these different familiness dimensions interact, reinforce or hamper each other constitutes an interesting question that may contribute to the understanding of the uniqueness and distinctiveness of family firms (Chrisman et al. 2005). To date, however, evidence on how these dimensions are intertwined is narrative at best. This study takes a first step in addressing this gap by analyzing the relation between business family identity (BFI) and transgenerational orientation (TGO). Referring back to the findings, a strong business family identity is a way of leveraging the TGO as a key aspect of the essence of family influence. Hence, when family members identify strongly with their business, they encourage actions in line with this identity (Ashforth and Mael 1989) and as such leverage the familiness of the business. FGM constitute means of strengthening the business family's identity and as a further consequence can also foster the familiness of the business.

\subsection{Implications for practice}

With regards to practical implications, this study highlights that FGM can help to strengthen a joint identity as a business family, which in turn fosters the TGO of the family business. As illustrated in the story of the Gucci family at the beginning of this article, a lack of family governance considerations and a lack of a joint identity as a business family can endanger the business family's long-term commitment to the business. This paves the way for opportunistic behaviors among single family members and can put the long-term continuity of the family business at risk. Therefore, regular communication and governance structures in the business family seem to be vital in order to develop joint expectations and decision premises with regard to the business. Although the family may feel a little uncomfortable when talking about business issues in a family setting in the beginning, family governance can be a valuable means to integrate the next generation early enough, to arouse their interest in business matters and to strengthen their commitment to business continuity (c.f. Jaskiewicz et al. 2015). Hence, FGM are important drivers for a joint identity as a business family and for the transgenerational orientation of the family business.

There are different ways of organizing the family through FGM. The business family may hold regular family meetings as long as the number of family members is still small and subsequently select a family council once the family grows larger. Furthermore, the family may also decide to develop a family constitution as an expression of the family's values, goals and its commitment to the business (c.f. Suess 2014). The stronger the business family's emphasis on family governance becomes, the more FGM become institutionalized and a family governance system consisting of multiple measures is likely to have a stronger effect on the family and the business than single random measures alone (see also Mustakallio et al. 2002). To conclude, the efforts invested in the development of FGM may pay off both through financial (cf. Berent-Braun and Uhlaner 2012) and non-financial benefits. 


\subsection{Limitations and future research directions}

It is necessary to point out that this study is not without limitations. First, FGM were measured through a categorical variable in this study. However, there was no information about the content that business families discuss in the context of FGM. Although the business family's identity and the transgenerational orientation for the business may be central topics, there might also be other issues of relevance (e.g. conflict management). This needs to be considered when interpreting the results. For future research, it would be fruitful to study both the context in which FGM are developed, as well as the content that is discussed. Case studies might be especially suitable for this purpose, because they allow greater insight into the family system (c.f. Lueger and Frank 2015). Furthermore, a scale development process in the sense of latent variable measurement is timely and relevant to better grasp the implicit principles and rules behind family governance structures. This is also in line with the general demand in family business research that "better measures of relevant constructs are needed as the field of family business continues to mature" (Pearson et al. 2014, p. 568). Therefore, the development of a psychometrically sound and theory-based scale is required in order to facilitate a cumulative progress of knowledge in research on family governance.

Second, the sample consisted mainly of smaller business families that are often involved in the governance of a sole business. Although the sample composition tends to be representative of the majority of business families in Austria, it does not fully account for families that hold ownership in multiple businesses and see themselves as portfolio entrepreneurs. Business families can indeed be multifaceted and may dynamically change over time. Especially larger business families may develop differentiated structures including multiple family branches that each develop their own business family identity. Moreover, in every family there might be a hierarchic differentiation which may not necessarily correspond to the ownership structure, but rather to experience, seniority, gender or other criteria. While part of the family and business complexity has been captured through control variables, this does of course not entirely capture the heterogeneity of business families and their family businesses. Therefore, future research could investigate which FGM are implemented by different types of business families, which identity these different types of business families develop and which effects this can have on TGO.

Third, the sample composition might not be the ideal one for studying family governance. While informal family meetings are used by the majority of business families, formal measures such as family constitutions and family councils might be more common in larger business families who often face a higher level of complexity (Brenes et al. 2011). Therefore, the relations between FGM, BFI and TGO might be even stronger when analyzed in a sample of larger business families with more complex family structures which deserves further attention in future research. Moreover, future research should also account for business families that hold ownership and/or management in multiple businesses and see themselves as portfolio entrepreneurs. 
Fourth, TGO as a decision premise appears to be a vital precondition for keeping the business in family hands. Nevertheless, the existence of a decision premise does not imply a logical or causal effect on decisions (Luhmann 2011). This means that a strong TGO does not necessarily lead to successful intra-family succession. There might be other factors, including financial distress, or the absence of a qualified and/ or willing successor, that make external succession, business closure or business sale more appealing options. The use of longitudinal data could help to clarify this potential discrepancy between TGO and intra-family succession by investigating how different levels of TGO are actually linked to succession decisions and ultimately to succession performance.

Fifth, the effect of FGM might not only depend on the fact that the business family possesses these measures, but rather on the importance that the business family actually attaches to them. This importance might range from rather insignificant formal acts to fundamental governance instruments that help to manage the family's influence in the business and strategic business development. However, to be fully effective, FGM need to be brought to life. Hence, future research on family governance might also consider the actual usage of FGM and the relevance that business families attach to these measures. This might also require the development of a scale for measuring family governance which focuses not only on manifest structures, but also on the family's actual principles and practices concerning family governance. Furthermore, cultural aspects might also play a role when it comes to explaining the dominance of certain FGM. For instance, family governance is more common in the US than in many European countries and also tends to comprise of a broader spectrum of measures, such as different specialist committees (e.g. education committees for the next generation) or websites and newsletters for regular family communication (Baus 2013). Therefore, studying the effects of a broader range of FGM (in a context where these are widely spread) on business continuity constitutes another possibility for future research.

\section{Conclusion}

The continuity of the family business depends considerably on the associated family that can either serve as a great source of strength or be a heavy burden on the business (Baus 2013). Therefore, understanding how the family can contribute or hinder the development of a transgenerational orientation for the business not only constitutes a central topic in family business research, but is also of high practical interest. As the family tree grows, family ties usually become looser, family involvement in the business varies, family members become inclined to pursue diverging goals and their identification with the business tends to weaken (Zellweger and Kammerlander 2015). This paves the way for family conflicts and opportunistic behavior that may affect the longterm success and sustainability of the family business (Kidwell et al. 2012). 
Family business governance is often used to counteract these problems (Siebels and Knyphausen-Aufseß 2012). However, although we can witness numerous studies that investigate the role of contractual governance in assuring the best possible family business performance from a business-level perspective (e.g. Anderson and Reeb 2004; Corbetta and Salvato 2004; Klein et al. 2005), comparatively little research has been conducted from a family-level perspective. Yet frequently the perpetuation of family control and influence over the business across generations tends to have higher priority than purely financial considerations in family businesses (Berrone et al. 2012). This study addresses this gap by taking a family-level perspective to analyze how family governance measures (FGM) as a form of relational governance (Mustakallio et al. 2002) can strengthen business family identity and how this in turn can affect the transgenerational orientation of the business. Applying a new systems theory (Luhmann 1995; von Schlippe and Frank 2013) and social identity theory approach (Tajfel and Turner 1979; Turner 1984; Waldkirch 2015), it explains how FGM enhance communication within the business family (Mustakallio et al. 2002) and create affective significance and a feeling of shared destiny for family members which strengthen their identification with the business. This shared business family identity leads family members to see the business as an extension of themselves and to enjoy family business success as personal success while suffering from business defeats (Deephouse and Jaskiewicz 2013). Hence functional family governance strengthens the family members' emotional investment in the business encouraging a strong business family identity that results in supportive behavior, family loyalty towards the business and the pursuance of a transgenerational orientation.

Finally, the field of family business research is still wide open for new empirical and conceptual studies along the lines of family governance, business family identity and transgenerational orientation. Investigating these topics would be a promising approach to gain a deeper understanding about the distinctiveness and uniqueness of this business type.

Acknowledgements I would like to thank the two anonymous reviewers for their constructive feedback that helped me to further develop this article. My special thanks also goes to my supervisor Hermann Frank, Andreas Hack (member of my doctoral committee) and my colleagues Jana Hauck and Alexander Kessler for their helpful feedback on earlier versions of this article that forms part of my paper-based doctoral dissertation. Furthermore, I would like to thank the participants of the conference for Germanspeaking family business research centers and institutes for family businesses (Konferenz der deutschsprachigen Forschungszentren und Institute für Familienunternehmen), held in Friedrichshafen/ Germany in March 2015. Last but not least, I wish to thank Lyndsay Jones and Katie Hyslop for their proofreading services. Open access funding provided by Vienna University of Economics and Business (WU).

Open Access This article is distributed under the terms of the Creative Commons Attribution 4.0 International License (http://creativecommons.org/licenses/by/4.0/), which permits unrestricted use, distribution, and reproduction in any medium, provided you give appropriate credit to the original author(s) and the source, provide a link to the Creative Commons license, and indicate if changes were made. 


\section{Appendix: List of variables}

\begin{tabular}{|c|c|c|}
\hline Variable & Item & Scale \\
\hline \multirow[t]{4}{*}{$\begin{array}{l}\text { Family governance } \\
\text { measures (FGM) }\end{array}$} & $\begin{array}{l}\text { Do you have regular discussions about business matters } \\
\text { within the family circle? [informal family meetings] }\end{array}$ & $\begin{array}{l}0=\text { no } \\
1=\text { yes }\end{array}$ \\
\hline & $\begin{array}{l}\text { Do you have formal family meetings in which business } \\
\text { matters are discussed as part of the agenda? [formal } \\
\text { family meetings] }\end{array}$ & $\begin{array}{l}0=\text { no } \\
1=\text { yes }\end{array}$ \\
\hline & $\begin{array}{l}\text { Is there a family council, or a similar body, that advises } \\
\text { management when important decisions have to be } \\
\text { made? [family council] }\end{array}$ & $\begin{array}{l}0=\text { no } \\
1=\text { yes }\end{array}$ \\
\hline & $\begin{array}{l}\text { Is there a family constitution, or a similar agreement, in } \\
\text { which the values and goals of the owning family are } \\
\text { clearly written out? [family constitution] }\end{array}$ & $\begin{array}{l}0=\text { no } \\
1=\text { yes }\end{array}$ \\
\hline $\begin{array}{l}\text { Transgenerational } \\
\text { orientation (TGO) }\end{array}$ & $\begin{array}{l}\text { In our family business we take great care } \\
\ldots \text { to think in generations } \\
\ldots \text { to avoid selling the company to non-family members } \\
\ldots \text { that the company can be passed on to the next } \\
\text { generation }\end{array}$ & $\begin{array}{c}1=\text { does not } \\
\text { apply at all } \\
2=\text { largely } \\
\text { does not apply } \\
3=\text { somewhat } \\
\text { does not apply } \\
4=\text { applies } \\
\text { somewhat } \\
5=\text { largely } \\
\text { applies } \\
6=\text { completely } \\
\text { applies }\end{array}$ \\
\hline $\begin{array}{l}\text { Business family identity } \\
\text { (BFI) }\end{array}$ & $\begin{array}{l}\text { As an entrepreneurial family we take great care } \\
\ldots \text { that the family is emotionally tied to the company } \\
\ldots \text { that family members stick together } \\
\ldots \text { to spend enough time as a family also outside the } \\
\text { company } \\
\ldots \text { to act as one family in the public } \\
\ldots \text { that all family members working in the } \\
\text { company give their best }\end{array}$ & $\begin{array}{c}1=\text { does not } \\
\text { apply at all } \\
2=\text { largely } \\
\text { does not apply } \\
3=\text { somewhat } \\
\text { does not apply } \\
4=\text { applies } \\
\text { somewhat } \\
5=\text { largely } \\
\text { applies } \\
6=\text { completely } \\
\text { applies }\end{array}$ \\
\hline \multicolumn{3}{|l|}{ Control variables } \\
\hline Business age & In which year was your business first founded? & $\begin{array}{l}\text { The number } \\
\text { filled in blank }\end{array}$ \\
\hline Business size & $\begin{array}{l}\text { On average, how many employees were working in your } \\
\text { business in the year 2012? }\end{array}$ & $\begin{array}{l}\text { The number } \\
\text { filled in blank }\end{array}$ \\
\hline $\begin{array}{l}\text { No. of family members } \\
\text { working in the } \\
\text { business }\end{array}$ & $\begin{array}{l}\text { How many family members (yourself included) work in } \\
\text { the business? }\end{array}$ & $\begin{array}{l}\text { The number } \\
\text { filled in blank }\end{array}$ \\
\hline
\end{tabular}




\begin{tabular}{|c|c|c|}
\hline Variable & Item & Scale \\
\hline $\begin{array}{l}\text { No. of family generations involved in } \\
\text { business management }\end{array}$ & $\begin{array}{l}\text { How many generations are involved in the } \\
\text { management of the business? }\end{array}$ & $\begin{array}{l}1=\text { one } \\
\text { generation } \\
2=\text { two } \\
\text { generations } \\
3=\text { three } \\
\text { generations }\end{array}$ \\
\hline $\begin{array}{l}\text { No. of family generations holding } \\
\text { business ownership }\end{array}$ & $\begin{array}{l}\text { How many generations hold a share of } \\
\text { ownership in the business? }\end{array}$ & $\begin{array}{l}1=\text { one } \\
\text { generation } \\
2=\text { two } \\
\text { generations } \\
3=\text { three } \\
\text { generations }\end{array}$ \\
\hline
\end{tabular}

\section{References}

Albert SA, Whetten DA (1985) Organizational identity. In: Cummings LL, Staw BM (eds) Research in organizational behavior, vol 7. JAI, Greenwich, CT, pp 263-295

Anderson RC, Reeb DM (2004) Board composition: balancing family influence in S\&P 500 firms. Admin Sci Quart 49:209-237

Aronoff CE, Ward JL (2011) Family meetings. How to build a stronger family and a stronger business, 2nd edn. Family Enterprise Publishers, Marietta, GA

Ashforth BE, Mael F (1989) Social identity theory and the organization. Acad Manage Rev 14:20-39

Astrachan JH (2010) Introduction to volume 1. J Family Bus Strat 1:1-5

Astrachan JH, Kolenko TA (1994) A neglected factor explaining family business success: human resource practices. Fam Bus Rev 7:251-262

Bammens Y, Voordeckers W, Van Gils A (2008) Boards of directors in family firms: a generational perspective. Small Bus Econ 31:163-180

Baron RM, Kenny DA (1986) The moderator-mediator variable distinction in social psychological research: conceptual, strategic and statistical considerations. J Pers Soc Psychol 51:1173-1182

Baus K (2013) Die Familienstrategie. Wie Familien ihr Unternehmen über Generationen sichern, 4. Aufl. Gabler Verlag, Wiesbaden

Berent-Braun MM, Uhlaner LM (2012) Family governance practices and teambuilding: paradox of the enterprising family. Small Bus Econ 38:103-119

Berrone P, Cruz C, Gomez-Mejia LR (2012) Socioemotional wealth in family firms. Theoretical dimensions, assessment approaches, and agenda for future research. Fam Bus Rev 25:258-279

Blumentritt TP (2006) The relationship between boards and planning in family businesses. Fam Bus Rev 19:65-72

Blumentritt TP, Keyt AD, Astrachan JH (2007) Creating an environment for successful nonfamily CEOs: an explanatory study of good principals. Fam Bus Rev 20:321-335

Botero IC, Gomez Betancourt G, Betancourt Ramirez JB, Lopez Vergara MP (2015) Family protocols as governance tools: understanding why and how family protocols are important in family firms. Journal of Family Business Management 5:218-237

Brenes ER, Madrigal K, Requena B (2011) Corporate governance and family business governance. J Bus Res 64:280-285

Brigham KH, Lumpkin GT, Payne TG, Zachary MA (2014) Researching long-term orientation: a validation study and recommendations for future research. Fam Bus Rev 27:72-88

Calabrò A, Mussolino D (2013) How do boards of directors contribute to family SME export intensity? The role of formal and informal governance mechanisms. J Manage Governance 17:363-403

Chittoor R, Das R (2007) Professionalization of management and succession performance: a vital linkage. Fam Bus Rev 20:65-79 
Chrisman JJ, Chua JH, Sharma P (2005) Trends and directions in the development of a strategic management theory of the family firm. Entrep Theory Pract 29:555-576

Chua JH, Chrisman JJ, Sharma P (1999) Defining the family business by behavior. Entrep Theory Pract 23:19-39

CNBC (2016) Famous family business feuds. CNBC LLC. http://www.cnbc.com/2011/01/31/Famousfamily-business-feuds.html?slide=6. Accessed 5 April 2016

Cohen J, Cohen P (1983) Applied multiple regression/correlation analysis for the behavioral sciences, 2nd edn. Lawrence Erlbaum Associates, Mahwah, NJ

Corbetta G, Salvato CA (2004) The board of directors in family firms: one size fits all? Fam Bus Rev 17:119-134

Craig J, Moores K (2002) How Australia's Dennis family corp. professionalized its family business. Fam Bus Rev 15:59-70

Deephouse DL, Jaskiewicz P (2013) Do family firms have better reputations than non-family firms? An integration of socioemotional wealth and social identity theories. J Manage Stud 50:337-360

Dyer WG (2003) The family: the missing variable in organizational research. Entrep Theory Pract 27:401-416

Dyer WG, Whetten DA (2006) Family firms and social responsibility: preliminary evidence from the S\&P 500. Entrep Theory Pract 30:785-802

European Commission (2003) Commission recommendation concerning the definition of micro, small and medium-sized enterprises. Official Journal L 124, 20/05/2003 P. 0036 - 0041. http://eur-lex. europa.eu/LexUriServ/LexUriServ.do?uri=CELEX:32003H0361:EN:NOT. Accessed 25 November 2014

Fahed-Sreih J (2009) An exploratory study on a new corporate governance mechanism. Evidence from small family firms. Management Research News 32:50-61

Fahed-Sreih J, Djoundourian S (2006) Determinants of longevity and success in Lebanese family businesses: an exploratory study. Fam Bus Rev 19:225-234

Frank H, Kessler A, Rusch T, Suess J, Weismeier-Sammer D (2016) Capturing the familiness of family businesses: Development of the family influence familiness scale (FIFS). Entrep Theory Pract doi:10.1111/etap.12229

Froschauer U, Lueger M (2015) Informalität als organisationaler Basisrhythmus. Beobachtungen in Familienunternehmen. In: von Groddeck V, Wilz SM (Hrsg) Formalität und Informalität in Organisationen. Springer, Wiesbaden, S 191-213

Fuetsch E, Frank H (2015) Die Familienverfassung: Strukturierung der Beziehung zwischen Familie und Unternehmen. In: Lueger M, Frank H (Hrsg) Zukunftssicherung für Familienunternehmen. Good Practice Fallanalysen zur Family Governance. Facultas, Wien, S 93-115

Gallo M, Kenyon-Rouvinez D (2005) The importance of family and business governance. In: KenyonRouvinez D, Ward JL (eds) Family business: Key issues. Palgrave/Macmillan, New York, pp 45-57

Gersick KE, Feliu N (2014) Governing the family enterprise: Practices, performance and research. In: Melin L, Nordqvist M (eds) The SAGE handbook of family business. Sage, London, pp 196-225

Gersick KE, Davis JA, McCollom Hampton M, Lansberg I (1997) Generation to generation. Life cycles of a family business. Harvard Business School Press, Boston

Gilding M (2000) Family business and family change: individual autonomy, democratization, and the new family business institutions. Fam Bus Rev 13:239-250

Gioia D (1998) From individual to organizational identity. In: Whetten D, Godfrey P (eds) Identity in organizations: Building theory through conversations. Sage, London, pp 17-31

Gordon G, Nicholson N (2008) Family wars: Classic conflicts in family business and how to deal with them. Kogan Page Publishers, London, Philadelphia, PA

Habbershon TG, Astrachan JH (1997) Research note: perceptions are reality: how family meetings lead to collective action. Fam Bus Rev 10:37-52

Habbershon TG, Pistrui J (2002) Enterprising families domain: family-influenced ownership groups in pursuit of transgenerational wealth. Fam Bus Rev 15:223-237

Habbershon TG, Williams ML, MacMillan I (2003) A unified systems perspective of family firm performance. J Bus Venturing 18:451-465

Habbershon T, Nordqvist M, Zellweger T (2010) Transgenerational entrepreneurship. In: Nordqvist M, Zellweger T (eds) Transgenerational entrepreneurship: Exploring growth and performance in family firms across generations. Edward Elgar, Cheltenham, pp 1-38

Hack A (2009) Sind Familienunternehmen anders? Eine kritische Bestandsaufnahme des aktuellen Forschungsstands. Z Betriebswirt 2:1-29 
Hair JF, Black W, Babin BJ, Anderson RE (2010) Multivariate data analysis. A global perspective, 5th edn. Pearson Prentice Hall, Upper Saddle River, New Jersey

Hall PD (1988) A historical overview of family firms in the US. Fam Bus Rev 1:51-68

Handler WC (1994) Succession in family business: a review of the research. Fam Bus Rev 7:133-157

Jaffe DT, Lane SH (2004) Sustaining a family dynasty: key issues facing complex multigenerational business- and investment-owning families. Fam Bus Rev 17:5-18

James HS (1999) Owner as manager, extended horizons and the family firm. Int J Econ Bus 6:41-55

Jaskiewicz P, Combs JG, Rau SB (2015) Entrepreneurial legacy: toward a theory of how some family firms nurture transgenerational entrepreneurship. J Bus Venturing 30:29-49

Kidwell RE, Kellermanns FW, Eddleston KA (2012) Harmony, justice, confusion, and conflict in family firms: implications for ethical climate and the "Fredo Effect', J Bus Ethics 106:503-517

Klein SB (2009) Komplexitätstheorem der corporate governance in familienunternehmen. Z Betriebswirt 2:63-82

Klein P, Shapiro D, Young J (2005) Corporate governance, family ownership and firm value: the Canadian evidence. Corp Gov 13:769-784

Koeberle-Schmid A, Brockhoff K, Witt P (2009) Performanceimplikationen von Aufsichtsgremien in deutschen Familienunternehmen. Z Betriebswirt 2:83-112

Koeberle-Schmid A, Witt P, Fahrion HJ (2012) Family Business Governance als Erfolgsfaktor von Familienunternehmen. In: Koeberle-Schmid A, Fahrion HJ, Witt P (Hrsg) Family Business Governance. Erfolgreiche Führung von Familienunternehmen, 2. Aufl. Erich Schmidt Verlag, Berlin, S 26-44

Labaki R (2011) The Nova Group case study: family dynamics in a multigenerational French family business. Int J Manag Cases 13:27-42

Lansberg I (1999) Succeeding generations: realizing the dream of families in businesses. Harvard University School Press, Boston

Lawler EE (1989) With HR help, all managers can practice high-involvement management. Personnel, April:26-31

Le Breton-Miller I, Miller D (2006) Why do some family businesses out-compete? Governance, longterm orientations, and sustainable capability. Entrep Theory Pract 30:731-746

Lueger M, Frank H (2015) Zukunftssicherung für Familienunternehmen. Good Practice Fallanalysen zur Family Governance, Facultas

Luhmann N (1984) Soziologische Aspekte des Entscheidungsverhaltens. DBW 44:591-603

Luhmann N (1995) Social systems. Stanford University Press, Stanford

Luhmann N (2011) Organisation und Entscheidung. Westdeutscher Verlag, Opladen

Lumpkin GT, Brigham KH (2011) Long-term orientation and intertemporal choice in family firms. Entrep Theory Pract 35:1149-1169

Lumpkin GT, Dess GG (2013) Strategy in family businesses: Recent findings and future challenges. In: Sorenson RL, Yu A, Brigham KH, Lumpkin GT (eds) The landscape of family business. Edgar Publishing, Northampton, pp 93-112

Lumpkin GT, Brigham KH, Moss TW (2010) Long-term orientation: implications for the entrepreneurial orientation and performance of family businesses. Entrep Region Dev 22:241-264

Martin HF (2001) Is family governance an oxymoron? Fam Bus Rev 14:91-96

Maul C (1993) Der Beitrag der Systemtheorie zum strategischen Führungsverhalten in komplexen Situationen. Z Betriebswirt 63:715-740

May P (2012) Einführung. In: Koeberle-Schmid A, Fahrion HJ, Witt P (Hrsg) Family Business Governance. Erfolgreiche Führung von Familienunternehmen, 2. Aufl. Erich Schmidt Verlag, Berlin, S 9-10

Michiels A, Voordeckers W, Lybaert N, Steijvers T (2015) Dividends and family governance practices in private family firms. Small Bus Econ 44:299-314

Mussolino D, Calabrò A (2014) Paternalistic leadership in family firms: types and implications for intergenerational succession. J Family Bus Strat 5:197-210

Mustakallio M, Autio E, Zahra SA (2002) Relational and contractual governance in family firms: effects on strategic decision making. Fam Bus Rev 15:205-222

Neubauer F, Lank AG (1998) The family business: Its governance for sustainability. Macmillan Press, London

Nordqvist M, Zellweger T (2010) Transgenerational entrepreneurship. Edward Elgar, Cheltenham

Olson PD, Zuiker VS, Danes SM, Stafford K, Heck RKZ, Duncan KA (2003) The impact of the family and the business on family business sustainability. J Bus Venturing 18:639-666 
Pearson AW, Holt DT, Carr JC (2014) Scales in family business studies. In: Melin L, Nordqvist M, Sharma P (eds) The SAGE handbook of family business. Sage, London, pp 551-572

Pieper TM, Astrachan JH (2008) Mechanisms to assure family business cohesion: Guidelines for family business leaders and their families. Cox Family Enterprise Center, Kennesaw

Podsakoff PM, Organ DW (1986) Self-reports in organizational research: problems and prospects. J Manage 12:531-544

Poppo L, Zenger T (2002) Do formal contracts and relational governance function as substitutes or complements? Strategic Manage J 23:707-725

Ravasi D, Schultz M (2006) Responding to organizational identity threats: exploring the role of organizational culture. Acad Manag J 49:433-458

Reicher S, Spears R, Haslam A (2010) The social identity approach in social psychology. In: Wetherell M, Mohanty CT (eds) The SAGE Handbook of Identities. Sage, London, pp 45-63

Schulze WS, Lubatkin MH, Dino RN, Buchholtz AK (2001) Agency relationships in family firms: theory and evidence. Organ Sci 12:99-116

Seidl D (2003) Organizational identity in Luhmann's theory of social systems. In: Bakken T, Hernes T (eds) Autopoietic organization theory. Drawing on Niklas Luhmann's social systems perspective. Copenhagen Business School Press, Oslo, pp 123-150

Seidl D (2005) The basic concepts of Luhmann's theory of social systems. In: Seidl D, Becker KH (eds) Niklas Luhmann and organization studies. Liber \& Copenhagen Business School Press, Malmö, Copenhagen, pp 21-53

Siebels JF, Knyphausen-Aufseß D (2012) A review of theory in family business research: the implications for corporate governance. Int J Manag Rev 14:280-304

Sieger P, Zellweger T (2013) Entrepreneurial families: From a family enterprise to an entrepreneurial family. HSG and Credit Suisse AG

Simon FB (2012) Einführung in die Theorie des Familienunternehmens. Carl-Auer Verlag, Heidelberg

Smidts A, Pruyn ATH, van Riel CBM (2001) The impact of employee communication and perceived external prestige on organizational identification. Acad Manage J 44:1051-1062

Sobel ME (1982) Asymptotic confidence intervals for indirect effects in structural equation models. In: Leinhart S (ed) Sociological methodology. Jossey-Bass, San Francisco, pp 290-312

Sorenson RL, Goodpaster KE, Hedberg PR, Yu A (2009) The family point of view, family social capital, and firm performance: an exploratory test. Fam Bus Rev 22:239-253

Suáre KC, Santana-Martín DJ (2004) Governance in Spanish family business. Int J Entrepren Behav Res 10:141-163

Suess J (2014) Family governance: literature review and the development of a conceptual model. J Family Bus Strat 5:138-155

Sundaramurthy C (2008) Sustaining trust within the family business. Fam Bus Rev 21:89-102

Sundaramurthy C, Kreiner GE (2008) Governing by managing identity boundaries: the case of family businesses. Entrep Theory Pract 32:415-436

Süss-Reyes J (2015) Implementierung einer komplexen Family Governance Lösung: Kontext, Prozess und Wirkungen. In: Lueger M, Frank H (Hrsg) Zukunftssicherung für Familienunternehmen. Good Practice Fallanalysen zur Family Governance. Facultas, Wien, S 141-174

Tajfel H (1982) Social psychology of intergroup relations. Annu Rev Psychol 33:1-39

Tajfel H, Turner JC (1979) An integrative theory of intergroup conflict. In: Austin WG, Worchel S (eds) The social psychology of intergroup relations, vol 33., Brooks/ColeMonterey, CA, pp 38-43

Tajfel H, Billig MG, Bundy RP, Flament C (1971) Social categorization and intergroup behaviour. Eur J Soc Psychol 1:149-178

Thoits PA, Virshup LK (1997) Me's and we's: Forms and functions. In: Ashmore RD, Jussim L (eds) Self and identity: Fundamental issues. Rutgers series on self and social identity. Oxford University Press, New York, pp 106-133

Turner JC (1984) Social identification and psychological group formation. In: Tajfel H (ed) The social dimension: European developments in social psychology, vol 2. Cambridge University Press, Cambridge, pp 518-538

Turner JC, Brown RJ, Tajfel H (1979) Social comparison and group interest in ingroup favouritism. Eur J Soc Psychol 9:187-204

Uhlaner LM, Kellermanns FW, Eddleston KA, Hoy F (2012) The entrepreneuring family: a new paradigm for family business research. Small Bus Econ 38:1-11

Van Den Heuvel J, Van Gils A, Voordeckers W (2006) Board roles in small and medium-sized family businesses: performance and importance. Corp Gov 14:467-485 
Von Schlippe A, Frank H (2013) The theory of social systems as a framework for understanding family businesses. Fam Relat 62:384-398

Von Schlippe A, Buberti C, Groth T, Plate M (2009) Die zehn Wittener Thesen. Familienunternehmen. In: Rüsen TA, von Schlippe A, Groth T. (Hrsg) Exploration einer Unternehmensform. Josef Eul, Lohmar/Köln, S 1-24

Waldkirch M (2015) Social identity theory and the family business. In: Nordqvist M, Melin L, Waldkirch M, Kumeto G (eds) Theoretical perspectives on family businesses. Edward Elgar, Cheltenham/ Northhampton, pp 137-155

Ward JL (1997) Growing the family business: Special challenges and best practices. Fam Bus Rev 10:323-337

Ward JL (2004) Perpetuating the family business. 50 lessons learned from long-lasting, successful families in business. Palgrave MacMillan, Basingstoke

Weismeier-Sammer D, Frank H, von Schlippe A (2013) Untangling "familiness": a literature review and directions for future research. Int J Entrepren Innov 14:165-177

Whetten D, Foreman P, Dyer WG (2014) Organizational identity and the family business. In: Melin L, Nordqvist M (eds) The SAGE handbook of family business. Sage, London, pp 480-497

Wimmer R, Gebauer A (2004) Die Nachfolge in Familienunternehmen. Zeitschrift für Organisation 73:244-252

Wimmer R, Domayer E, Oswald M, Vater G (2005) Familienunternehmen: Auslaufmodell oder Erfolgstyp?, 2nd edn. Gabler, Wiesbaden

Zachary RK (2011) The importance of the family system in family business. Journal of Family Business Management 1:26-36

Zahra SA, Sharma P (2004) Family business research: a strategic reflection. Fam Bus Rev 17:331-346

Zellweger TM, Kammerlander N (2014) Family Business Groups in Deutschland: Generationenübergreifendes Unternehmertum in grossen deutschen Unternehmerdynastien. Working paper of the Center for Family Business der Universität St. Gallen

Zellweger T, Kammerlander N (2015) Family, wealth and governance. An agency account. Entrep Theory Pract 39:1281-1303

Zellweger T, Sieger P (2012) Entrepreneurial orientation in long-lived family firms. Small Bus Econ 38:67-84

Zellweger TM, Eddleston K, Kellermanns FW (2010) Exploring the concept of familiness: introducing family firm identity. J Family Bus Strat 1:54-63

Zellweger TM, Nason RS, Nordqvist M, Brush CG (2011) Why do family firms strive for nonfinancial goals? An organizational identity perspective. Entrep Theory Pract 37:229-248

Zellweger TM, Kellermanns FW, Chrisman JJ, Chua JH (2012a) Family control and family firm valuation by family CEOs: the importance of intentions for transgenerational control. Organ Sci 23:851-868

Zellweger TM, Nason RS, Nordqvist M (2012b) From longevity of firms to transgenerational entrepreneurship of families: introducing family entrepreneurial orientation. Fam Bus Rev 25:136-155 